\title{
Trace Elements and Cancer
}

\author{
Elena POPESCU ${ }^{1,2}$, Ana Maria Alexandra STANESCU
}

\begin{abstract}
The role of the trace elements in humans has increased during the last 20 years. It seems that they play a significant role in maintaining the healthy state of the organism. These minerals are present in small levels, but their role is vital. Although they account for only $0.02 \%$ of the total body weight, it has highlighted that they play significant roles, either as active centers of enzymes or as trace bioactive substances. Their excess or deficiency may influence the homeostasis and potentially can lead to several chronic diseases, including cancer. It is already known that certain elements in the free or combined state can be primary causative agents, or risk factors for human cancer. Nevertheless, it is important to underline that the carcinogenic elements are fewer than it was expected in studies. Copper, cobalt, chromium, zinc, selenium, are involved in many biochemical processes supporting life. However, their concentrations may play an important role in developing cancer, by influencing proliferation or apoptosis. Disruption of the balance between free radicals and antioxidants may cause a cellular damage and trigger carcinogenesis.
\end{abstract}

Keywords: trace elements, cancer, oxidative stress, chronic deficiency, excess.

\section{Rezumat}

Rolul oligoelementelor la om a crescut în ultimii 20 de ani. Se pare că acestea joacă un rol semnificativ în menținerea homeostaziei organismului. Aceste minerale sunt prezente in cantități mici, dar rolul lor este vital. Deși reprezintă doar 0,02\% din greutatea corporală totală, este de subliniat că joacă roluri semnificative, fie ca centre active ale enzimelor, fie in componența unor substanțe bioactive. Excesul sau deficitul lor poate influența homeostazia și poate duce la boli cronice, inclusiv la cancer. Se știe deja că anumite elemente, în stare liberă sau combinate, pot reprezenta agenți cauzali primari, sau factori de risc pentru cancerul la om. Cu toate acestea, este important să subliniem că elementele cancerigene sunt mai puține decât se aștepta în studii. Cupru, cobalt, crom, zinc, seleniu, sunt implicate în multe procese biochimice care susțin viața. Cu toate acestea, concentrațiile lor pot juca un rol important în dezvoltarea cancerului, prin influențarea proliferarii sau apoptozei. Întreruperea echilibrului dintre radicalii liberi și antioxidanți poate provoca o deteriorare celulară și poate declanșa carcinogeneza.

Cuvinte cheie: oligoelemente, cancer, stres oxidativ, deficit cronic, exces.

\section{INTRODUCTION}

Essential trace elements of the human body include zinc $(\mathrm{Zn})$, copper $(\mathrm{Cu})$, selenium $(\mathrm{Se})$, chromium $(\mathrm{Cr})$, cobalt (Co), iodine (I), manganese (Mn), and molybdenum $(\mathrm{Mo})^{1}$. Although these elements account for only $0.02 \%$ of the total body weight, they play significant roles, e.g., as active centers of enzymes or as trace bio- active substances ${ }^{2}$. With the exception of magnesium, all the trace metals are associated with enzymes (like copper in uricase, zinc in carbonic anhydrase, and iron in catalase). They are found in the periodic chart as transition elements, and are characterized by their ease of forming complex ions or chelates with appropriate organic molecules ${ }^{3}$. Also, it should be recognized that a

\footnotetext{
1 "Carol Davila" University of Medicine and Pharmacy, Bucharest, Romania

${ }^{2}$ Clinical Emergency Hospital of Ilfov County, Bucharest, Romania
}

Corresponding author.

Elena POPESCU, „Carol Davila" University of Medicine and

Pharmacy, Bucharest, Romania.

E-mail: dr.elenap@gmail.com 
combination of metals may be necessary for enzymatic function, such as magnesium and manganese in phosphorylase, and iron and molybdenum for xanthine oxidase in a ratio of 8:1:4. Metals, therefore, do interact in biological systems ${ }^{4}$.

Reducing oxidative stress, or enhancing the repair capacity of trace elements (such as $\mathrm{Se}, \mathrm{Zn}, \mathrm{Mn}$ ) relies on ability to act as essential cofactors for antioxidant enzymes such as $\mathrm{Cu}, \mathrm{Zn}$-superoxide dismutase, $\mathrm{Mn}$-superoxide dismutase, catalase $(\mathrm{Cu}, \mathrm{Fe})$, and the different types of glutathione peroxidases $(\mathrm{Se})$. These enzymes are mandatory for limiting oxidation of lipids, nucleic acids or proteins, which are involved in chronic diseases, such as cancers and cardiovascular disorders and also in ageing ${ }^{5}$.

Trace elements play a significant role in maintaining the healthy state of an organism. Consequently, disturbances in trace element homeostasis may result in the development of pathologic states and diseases. The deficiency occurs due to insufficient trace element content in diets or increased requirements of an organism. Nevertheless, the difference between "enough" and "too much" of these minerals is often tiny ${ }^{6,7}$. Furthermore, massive intake of one trace element will influence the absorption of others: molybdenum will affect copper retention; a deficiency of copper will limit the requirement for iron; copper may counteract zinc or molybdenum toxicity ${ }^{8}$. There is also the phenomenon of competition of one element with another for a site in a specific biological tissue. Both strontium and beryllium have an affinity for bone and can cause rickets, whereas all group VII elements of the periodic chart go to the thyroid gland.

Many epidemiological surveys and animal studies have demonstrated that health problems are caused by deficiency or excess of trace elements. Trace element deficiency or excess is one of the most difficult diagnosis ${ }^{9}$. The deficiencies show some general rules of development. All of them are followed by a decrease of immune response. The deficiency is never isolated and is always followed by a considerable disturbance of metabolism (mineral, lipid, carbohydrate and protein). As a result, there may be weight gain, reduced immune resistance, atherosclerosis or endocrine gland pathologies. All of these can favor the development of various malignancies ${ }^{10}$. Further on, the chronic deficiency leads to considerable metabolic disturbances and distinct clinical and morphological changes ${ }^{11}$. Both processes result in endocrinopathies, inflammations and neoplastic diseases ${ }^{12}$.
Recent evidence has suggested the role of Se in reducing the risk of a variety of malignancies. Proposed mechanisms for anti-cancer actions of Se include antioxidant protection, enhanced carcinogen detoxification, enhanced immune surveillance, modulation of cell cycle, inhibition of tumor cell invasion and inhibition of angiogenesis ${ }^{13}$. Additionally, studies showed that $\mathrm{Zn}$ supplement may protect against free radical damage ${ }^{14}$, or that $\mathrm{Zn}$ levels are decreased in patients with certain malignancies ${ }^{15}$. Se and $\mathrm{Zn}$ levels have been correlated to prostate cancer risk ${ }^{16}$. Higher Se levels are related to a lower risk of many types of neoplasms, including lung, colorectal, prostate and possibly bladder ${ }^{17,18}$.

Natural trace elements such as zinc and copper have some dictatorial functions that may affect immune reactions and free radical generation ${ }^{19,20}$. Zinc $(\mathrm{Zn})$, copper $(\mathrm{Cu})$, and iron $(\mathrm{Fe})$ have been also implicated in various types of malignancies ${ }^{21}$.

Copper, zinc, selenium, and molybdenum are involved in important biochemical processes. The most important of these are cellular respiration, cellular utilization of oxygen, DNA and reproduction, maintenance of cell membrane integrity and sequestration of free radicals. In the same time, these elements are involved in destruction of free radicals through a cascade of enzyme systems (superoxide dismutase), in the presence of copper and zinc cofactors. Form this process hydrogen peroxide results, which is then reduced to water by the selenium-glutathione peroxidase couple. When the removal of these superoxide free radicals is efficient, the integrity of membranes is maintained and thus, the aging process and the risk of cancer decreases ${ }^{22}$.

Some studies showed elevated levels of $\mathrm{Cu}$ in bladder, breast, prostate, and liver cancers, and the $\mathrm{Cu} / \mathrm{Zn}$ ratio is proposed to be used as a biomarker,to assess patient's prognosis ${ }^{23}$. Oxidative stress is defined as animbalance between oxidant- antioxidant balance, in favor of the oxidant process. Chemical and physical agents, including those that induce reactive oxygen species (ROS), can induce and modulate this multistep activity. The human body produces certain antioxidants (scavenging enzymes) such as glutathione, superoxide dismutase (SOD) and catalase (CAT) that can counteract the harmful effects of ROS and protect against cellular and molecular damages. Breaking the balance between free radicals and antioxidants may cause a cellular damage which triggers the carcinogenesis ${ }^{24,25}$.

Some trace metals are supposed to play a carcinogenic role, inducing a toxic effect through the formation of ROS and acting as cofactors in the oxidative dama- 
ge of biological macromolecules and DNA ${ }^{26}$. However, their exact role in carcinogenesis is still unclear ${ }^{27}$.

Worldwide, there are more than 10 million new cancer cases each year, and cancer is the cause of approximately $12 \%$ of all deaths. A large number of epidemiologic studies have been made to identify the risk factors for cancer. Among these, an association with trace elements has received considerable attention ${ }^{28}$. Elements like selenium, zinc, arsenic, cadmium, and nickel, are found naturally in the environment, and human exposure derives from a variety of sources, including air, drinking water, and food. It has been also underlined that trace elements' levels of exposure are potentially modifiable $^{29}$.

A hundred years ago, it was suggested that cancer is a disease linked with chromosomes, based on the observations that whole chromosomes or chromosome arms are missing or duplicated in the genomes of cells in a tumor (aneuploidy). Furthermore, based on basic researches, another observation was made, highlighting that the concentrations of some trace elements, especially zinc, copper and iron are changed in tumor cells ${ }^{30}$. It is highlighted that the tumor zinc level, for example, is consistently elevated in some cancers (e.g., breast) and consistently decreased in others (e.g., prostate, pancreatic, liver). The effects of trace elements on proliferation and apoptosis are supposed to be cell type specific and may differ in normal and malignant cells ${ }^{31,32}$.

With regard to their concentrations, it was observed that they may have an influence on metastasis. Different types of metastases show deregulated trace element concentrations, compared to surrounding normal tissue $^{33}$. Cancer is a leading cause of death worldwide, accounting for an estimated 9.6 million deaths in 2018 . The most common cancers are: lung (2.09 million cases), breast (2.09 million cases), colorectal (1.80 million cases), prostate (1.28 million cases). The most common causes of cancer death are cancers of: lung (1.76 million deaths), colorectal (862 000 deaths), stomach (783 000 deaths), liver (782 000 deaths) and breast (627 000 deaths $)^{34}$.

\section{BREAST CANCER}

Breast cancer is the most frequent cancer among women, impacting 2.1 million women each year, and also causes the greatest number of cancer-related deaths among women. In 2018, it is estimated that 627,000 women died from breast cancer - that is approximately $15 \%$ of all cancer deaths among women. While breast cancer rates are higher among women in more develo- ped regions, rates are increasing in nearly every region globally ${ }^{34}$. It is also the most commonly diagnosed one, widespread affecting 1 in 8 women ${ }^{35}$. The official WHO data show that the risk of breast cancer rises with age, reaching the highest point in postmenopausal women.

Although the mechanisms of breast cancer disease are better understood, it is still the most frequent malignant tumor in women and one of the leading causes of cancer death ${ }^{36}$. The relationship between serum levels of trace elements and breast cancer remainsunclear $^{37}$. Nevertheless, they play important roles in biological processes relevant to breast cancer, especially by influencing the elements that are essential antioxidants components. Although several articles tried to identify associations between trace element levels and breast cancer in different populations, using different samples, like hair, toenails, or blood, their conclusions have been inconsistent ${ }^{38}$. Several analytical methods have been used to identify and measure trace elements. $\mathrm{X}$-ray fluorescence spectroscopy, atomic absorption spectroscopy (AAS), inductively coupled plasma mass spectrometry (ICP-MS), and inductively coupled plasma atomic emission spectroscopy (ICP-AES) are the most used methods ${ }^{39}$.

A comparative analysis of epidemiological data for breast cancer in the USA, Canada, India, China, Taiwan, Japan, South Korea, and Sweden showed notable differences in the median age at diagnosis; the peak age at diagnosis being 40-50 years in Asian countries, and 60-70 years in Western countries ${ }^{40}$. The major known risk factors for breast cancer include female sex, age, and family history, as well as reproductive factors, including early age at menarche, later menopause, nulliparity, and first childbirth after age 30 . All of these are independent risk factors ${ }^{41}$.

There are some studies that show that lower iron level is linked to colorectal, or breast cancer. Some, did not found any link between iron levels and the risk of breast cancer ${ }^{42}$. Changes in calcium, copper, iron, magnesium and zinc concentrations were also detected in breast cancer patients, compared with the healthy population. The ratios of $\mathrm{Ca} / \mathrm{Mg}, \mathrm{Cu} / \mathrm{Zn}$ and $\mathrm{Cu} / \mathrm{Fe} \mathrm{Co}^{-}$ uld be used as biochemical markers in these patients ${ }^{43}$. Most data have reported no association between selenium and risk of breast, colorectal, and stomach cancer, and between zinc and prostate cancer risk. There is compelling evidence in support of positive associations between arsenic and risk of both lung and bladder cancers, and between cadmium and lung cancer risk ${ }^{44}$. 


\section{PROSTATE CANCER}

Prostate cancer is one of the most prevalent male cancer all over the world. Globally, prostate cancer ranks second in incidence and the fifth in mortality in men, and represents an important public health issue ${ }^{45}$. Prostate cancer incidence is rising rapidly in Asia too, probably because of the aging population, westernized dietary habits and increasing use of prostate-specific antigen (PSA) testing ${ }^{46-48}$.

It was also revealed that in the prostatic fluid of cancerous prostate $\mathrm{Zn}$ was significantly lower, compared with those in the prostatic fluid of hyperplastic prostate ${ }^{49}$. The decrease in levels of $\mathrm{Zn}$ in the prostatic fluid of cancerous prostate might demonstrate an involvement of these trace elements in the etiology and pathogenesis of malignant prostate tumors. It is supposed that the changes of $\mathrm{Zn}$ levels can be used as tumor markers ${ }^{50,51}$.

Cadmium $(\mathrm{Cd})$ is recognized as a carcinogen ${ }^{52}$, based particularly on studies made on individuals having substantial occupational exposure via the respiratory system. Once absorbed, Cd binds to metallothionein and is stored mainly in the kidneys and liver. Prostate tissue has also been identified as a target for $\mathrm{Cd}$ deposition $^{53}$. In a recent populational prospective study, dietary $\mathrm{Cd}$ exposure was associated with a slightly increased overall risk of prostate cancer and for localized disease, the risk was more marked in smokers and lean men $^{54}$.

Magnesium ( $\mathrm{Mg})$ is the second most abundant intracellular cation in the body, involved with numerous biological activities, particularly related to its interaction with $\mathrm{Ca}$. Serum $\mathrm{Mg}$ levels, and $\mathrm{Ca} / \mathrm{Mg}$ ratio have been shown to be associated with high-grade prostate cancer ${ }^{55} . \mathrm{Mg}$ deficiency is linked to chronic inflammation, possibly due to the concurrent $\mathrm{Ca}$ levels. Furthermore, it is speculated that $\mathrm{Ca}$ may play a key role in the progression of prostate cancer ${ }^{56}$.

Copper $(\mathrm{Cu})$ appears to play also an important role in the carcinogenic process. This fact is evident through the $\mathrm{Cu}$ high levels observed in cancerous tissues ${ }^{57}$.

\section{COLON CANCER}

Colorectal cancer is still the third leading cause of the cancer causes in the world, with an increased incidence in the developing countries. A number of studies have shown that dietary calcium intake is associated with a reduced incidence of colon cancer among middle-aged subjects. Other observations suggested that alterations in essential trace elements like $\mathrm{Cu}, \mathrm{Fe}, \mathrm{Zn}$ and $\mathrm{Ca}$ may play an important role in the pathogenesis of this kind of cancer. Very few reports are available on the concentration of trace elements in colon cancer patients ${ }^{58}$.

Although Ca levels seemed to be high, it did not reach statistical significance. It was also found low iron concentrations in comparison with healthy controls, but with no statistical significance. On the other hand, serum $\mathrm{Zn}$ levels were significantly reduced. These decreased serum levels in in colon cancer patients may be due to the mobilization of circulating $\mathrm{Zn}$ to the colon cancer tissue. Therefore its involvement in the antioxidant defense since the patients might be under higher oxidative stress ${ }^{59}$.

\section{LUNG CANCER}

Copper, arsenic, chromium, lead, nickel and beryllium, are trace elements with possible implication in the cause of lung cancer. A high incidence of lung cancer has been demonstrated as an occupational disease among workers engaged in the chromate production process in Germany and the United States. This excess risk is believed to be the result of exposure to hexavalent chromium and not linked with smoking status ${ }^{60}$. As in other cancer causes, $\mathrm{Zn}$ levels seem to play a protective role also in lung cancer. In addition, it is suggested that low levels of zinc can facilitate the pathogenesis of lung cancer.

Copper is a mineral found in trace amounts in all tissues in the body. Although only a small amount is needed, copper is an essential nutrient that plays a role in the production of hemoglobin, myelin, collagen, and melanin. In one clinical study that followed over 1,600 patients with lung cancer found that dietary zinc and copper intakes are associated with reduced risk of lung cancer ${ }^{61}$. Exposure to potentially carcinogenic traceelements can occur as a result of both occupational and environmental sources. As, $\mathrm{Cd}, \mathrm{Ni}$ and other trace elements have been consistently linked to lung cancer in ecologic, cohort, and case-control studies ${ }^{62}$.

Another case-control study compared the results withother cancer patients from the same region. Contrary to initial hypothesis, based on previous studies, the authors found that there was no positive association between trace-element concentrations, in toenails and lung cancer ${ }^{63}$.

\section{CONCLUSIONS}

In recent years, the analysis of trace elements inhuman tissues has gained great interest due to the role that 
they play in biochemical and physiological processes. Although trace elements constitute a minor part of the tissue's compounds, they are important for almost all vital processes ${ }^{64}$.

World Health Organization has categorized 19 trace elements as essential to human health, including arsenic (As), cadmium $(\mathrm{Cd})$, nickel $(\mathrm{Ni})$, selenium $(\mathrm{Se})$, and zinc $(\mathrm{Zn})^{65}$.

However, in abnormal amount, they seem to contribute in several pathological processes, including tumor growth, invasion and metastasis ${ }^{66}$.

Arsenic levels have been found linked with cancer risk, focusing on the detection from drinking water. Some articles highlighted the role of $\mathrm{Cd}$ and $\mathrm{Ni}$ exposure levels in different workplaces. Also, the role of $\mathrm{Zn}$ in several cancer sites has been examined as well, while Se did not show a direct relation to cancer risk ${ }^{67}$. Other studies highlighted the effective role of Se in preventing cancers ${ }^{68}$. The mechanism of prevention include selenium role in arresting the cell cycle, decreasing cell proliferation, inducing apoptosis, DNA repair by $\mathrm{p} 53$ activation, disruption of androgen receptor indications, and acting as a core component of selenoenzymes,

\section{References}

1. Piccinini L, Borella P, Bargellini A, Medici Cl, Zoboli A. A casecontrol study on selenium, zinc, and copper in plasma and hair of subjects affected by breast and lung cancer. Biological Trace Element Research. 1996;51(1):23-30.

2. Bhattacharya PT, Mohsina H. Nutritional Aspects of Essential Trace Elements in Oral Health and Disease: An Extensive Review. Scientifica, 2016:1-12.

3. Skalnaya MG, Skalny AV. Essential trace elements in human health: a physician's view. - Monography, Tomsk: Publishing House of Tomsk State University, ISBN 978-5-94621-683-8, 2018. Pp. 7-15.

4. Saleh SAK, Adly HM, Abdulkhaliq A, Nassir AM. Correlation of Some Trace Elements Serum Levels with Prostate Cancer Progression in Saudi Patients. The Open Public Health Journal. 2019;12(1):212-18.

5. Papp LV, Lu J, Olmgren A, Khanna KK. From selenium to selenoproteins: synthesis, identity, and their role in human health. Antioxid Redox Sign 2007; 9: 775-806.

6. Margarita GS, Skalny AV. Essential trace elements in human health: A physician's view 2018. Tomsk Publishing House of Tomsk State University, ISBN 978-5-94621-683-8, 224 p.

7. Saleh SAK, Adly HM, Nassir AM. Altered Trace Elements Levels in Hair of Prostate Cancer Patients. Journal of Cancer Science \& Therapy. 2017;09(02). 336-339

8. Kulkarni N, Kalele K, Kulkarni M, Kathariya R. Trace Elements in Oral Health and Disease: An Updated Review. Journal of Dental Research and Review, 2014;1(2):100- 4.

9. Lingamaneni P, Kumar KK, Teja CR, Reddy BKR, Krishna PL.A Review on Role of Essential Trace Elements in Health and Disease. Journal of Dr. NTR University of Health Sciences. 2015; $4(2): 75-85$. which integrates selenium as selenocysteine, an infrequently incident amino acid, to its active center ${ }^{69}$.

A better understanding and application of traditional tumor biomarkers and the identification of new markers is essential since they improve the patients' quality of life, sparing them from going under toxic treatments that are unlikely to benefit from, and also by making possible to differentiate an appropriate individualized treatment for each type of tumor ${ }^{64}$.

More studies must be expected to enlighten the certain role of certain trace elements in cancer development. Knowing already that the era of biomarkers has an important development, it is challenging to establish some new reliable biomarkers based on the variations of the trace elements in different type of cancers. This possibility could represent a brighter future.

Compliance with ethics requirements: The authors declare no conflict of interest regarding this article. The authors declare that all the procedures and experiments of this study respect the ethical standards in the Helsinki Declaration of 1975, as revised in 2008(5), as well as the national law. Informed consent was obtained from all the patients included in the study.

10. Wada O. What are Trace Elements? Their deficiency and excess states. JMAJ. 2004:47(8): 351-358.

11. Zofkoda I, Davis M, Blahos J. Trace Elements Have Beneficial, as Well as Detrimental Effects on Bone Homeostasis. Physiol. Res. 2017;66: 391-402.

12. Preeti TB, Satya R M, Mohsina H. Nutritional Aspects of Essential Trace Elements in Oral Health and Disease: An Extensive Review. Hindawi Publishing Corporation Scientifica Volume 2016 $1-12$.

13. Méplan C. Trace elements and ageing, a genomic perspective using selenium as an example. Journal of Trace Elements in Medicine and Biology. 2011 (25); 511-516.

14. Mazdak H, Yazdekhasti F, Movahedian A, Mirkheshti N, Shafieian M. The comparative study of serum iron, copper, and zinc levels between bladder cancer patients and a control group. International Urology and Nephrology. 2009;42(1):89-93.

15. Bosland MC, Kato I, Zeleniuch-Jacquotte A, et al. Effect of Soy Protein Isolate Supplementation on Biochemical Recurrence of Prostate Cancer After Radical Prostatectomy. JAMA. 2013;310(2):170-178.

16. Platz EA, Helzlsouer KJ. Diet: Selenium, Zinc, and Prostate Cancer. Epidemiologic Reviews. 2001;23(1):93-101.

17. Rayman MP. Selenium in cancer prevention: a review of the evidence and mechanism of action. Proceedings of the Nutrition Society. 2005;64(4):527-42.

18. Brinkman M, Buntinx F, Muls E, Zeegers MP. Use of selenium in chemoprevention of bladder cancer. The Lancet Oncology. 2006;7(9):766-74.

19. Smith ML, Lancia JK, Mercer TI. Selenium compounds regulate $\mathrm{p} 53$ by common and distinctive mechanisms. Anticanc Res, 2004(24), 1401-1408. 
20. Ressnerova A, Raudenska M, Holubova M, et al. Zinc and Copper Homeostasis in Head and Neck Cancer: Review and MetaAnalysis. Current Medicinal Chemistry. 2016;23(13):1304-30.

21. Dawood SD. A Study of Serum Zinc, Iron, Selenium, and Copper levels in patients with bladder cancer. Iraqi Journal of Cancer and Medical Genetics. 2018;3(1):40-45.

22. Sinha DSK. Trace elements deficiency \& cancer. IOSR Journal of Pharmacy and Biological Sciences. 2014;9(4):21-32.

23. Fadhil HY, Aufi IM, Aboud RS, Tuma FL. Effect of Oral Zinc Sulfate on Local Inflammatory Cytokines Level in Iraqi Women Infected With Human Papilloma virus (HPV), IOSR Journal of Pharmacy and Biological Sciences, 2017 (12):14-17.

24. Gupte A, Mumper RJ. Elevated copper and oxidative stress in cancer cells as a target for cancer treatment. Cancer Treatment Reviews. 2009;35(1):32-46.

25. SinhaR, Singh R, Mehrotra S, Singh R. Implications of free radicals and antioxidant levels in carcinoma of the breast: A never-ending battle for survival. Indian Journal of Cancer. 2009; 46(2):146-150.

26. Klaunig JE, Wang Z, Pu X, Zhou S. Oxidative stress and oxidative damage in chemical carcinogenesis. Toxicol Appl Pharmacol, 2011; 254: 86-99.

27. Lawson M, Jomova K, Poprac P, Kuča K, Musílek K, Valko M. Free Radicals and Antioxidants in Human Disease. Nutritional Antioxidant Therapies: Treatments and Perspectives. 2017:283-305.

28. Okunade KS, Dawodu OO, Salako O, Osanyin GE, Okunowo AA, Anorlu RI. Comparative analysis of serum trace element levels in women with invasive cervical cancer in Lagos, Nigeria. Pan African Medical Journal. 2018(31);1-7.

29. Janak R, Mehrotra S, Singh RK. Implications of free radicals and antioxidant levels in carcinoma of the breast: A never-ending battle for survival. Indian Journal of Cancer 2009,46(2):146-50

30. Engelken J, Altmeyer M, Franklin RB. The Disruption of Trace Element Homeostasis Due to Aneuploidy as a Unifying Theme in the Etiology of Cancer. 2014;2-63.

31. Hornsby C, Page KM, Tomlinson IP. What can we learn from the population incidence of cancer? Armitage and Doll revisited. Lancet Oncol. 2007(8):1030-1038.

32. Franklin RB, Costello LC. The important role of the apoptotic effects of zinc in the development of cancers. Journal of Cellular Biochemistry. 2009;106(5):750-7.

33. Farquharson MJ, Al-Ebraheem A, Theodorakou $\mathrm{C}$, et al. Measurement of $\mathrm{K}, \mathrm{Fe}, \mathrm{Cu}$ and $\mathrm{Zn}$ levels in secondary colorectal liver cancer and surrounding normal liver tissue, and their potential as a tissue classifier. X-Ray Spectrometry. 2009;38(2):81-8.

34. WHO, Latest global cancer data, Press release,12 sept 2018. www.who.int (accessed 05 Nov 2019).

35. Burson AM, Soliman AS, Ngoma TA, et al. Clinical and Epidemiologic Profile of Breast Cancer in Tanzania. Breast Disease. 2010;31(1):33-4.

36. Eiro N, Gonzalez LO, Fraile M, Cid S, Schneider J, Vizoso FJ. Breast Cancer Tumor Stroma: Cellular Components, Phenotypic Heterogeneity, Intercellular Communication, Prognostic Implications and Therapeutic Opportunities. Cancers. 2019;11(5): $664 ; 1-26$.

37. ChoiR, Kim M-J, Sohn I, et al. Serum Trace Elements and Their Associations with Breast Cancer Subgroups in Korean Breast Cancer Patients Nutrients. 2018 (1):37, 1- 15

38. Adeoti M, Oguntola A, Akanni E, Agodirin O, Oyeyemi G. Trace elements; copper, zinc and selenium, in breast cancer afflicted female patients in LAUTECH Osogbo, Nigeria. Indian Journal of Cancer. 2015;52(1):106- 109.

39. Bolann BJ, Rahil-Khazen R, Henriksen $H$, Isrenn R, Ulvik RJ. Evaluation of methods for trace element determination with emphasis on their usability in the clinical routine laboratory. Scandinavian Journal of Clinical and Laboratory Investigation. 2007;67(4):353-66
40. SungH, Rosenberg PS, Chen W-Q, et al. Female Breast Cancer Incidence Among Asian and Western Populations: More Similar Than Expected. JNCl: Journal of the National Cancer Institute. 2015(7):1-7.

41. Ferlay J, Héry C, Autier P, Sankaranarayanan R. Global Burden of Breast Cancer. Breast Cancer Epidemiology. 2009;1-19.

42. Sarkar PD, Vamne A. Analysis of Serum Trace Elements (Copper, Iron and Zinc) Level in Women with Breast Cancer Sch. J App Med Sci. 2017(11B); 4420-4426.

43. Wang CT, Chang WT, Yang TL. Study of the Concentrations of Calcium, Copper, Iron, Magnesium and Zinc in the Hair of Breast Cancer Patients. Trace Elements and Electrolytes. 2006(23);10, 281-286.

44. Stephanie A, Navarro Nilvera, Thomas E, Rohan S. Trace elements and cancer risk: a review of the epidemiologic evidence, Cancer Causes \& Control, 2007 (18); 1: 7-27.

45. Zaichick V, Zaichick S. Significance of trace element quantities in the prostatic secretion of patients with benign prostatic hyperplasia and prostate cancer. J Cancer Metastasis Treat 2019(5):48, 1-9.

46. Shah S. Trace Minerals and Heavy Metals: Implications in Prostate Cancer. Bangladesh Journal of Medical Biochemistry. 2017;8(1):27-32.

47. Zaichick VY, Sviridova TV, Zaichick SV. Zinc concentration in human prostatic fluid: Normal, chronic prostatitis, adenoma and cancer. International Urology and Nephrology. 1996;28(5):68794

48. Zaichick V, Zaichick S. Trace Element Levels in Prostate Gland as Carcinoma's Markers. Journal of Cancer Therapy. 2017; 08(02):131-45

49. Zaichick VY, Sviridova TV, Zaichick SV. Zinc concentration in human prostatic fluid: Normal, chronic prostatitis, adenoma and cancer. International Urology and Nephrology. 1996;28(5):68794

50. Zaichick S, Zaichick V. Method and portable facility for energydispersive $\mathrm{X}$-ray fluorescent analysis of zinc content in needle-biopsy specimens of prostate. X-Ray Spectrometry. 2010; 39(2):83-9.

51. Zaichick VY, Sviridova TV, Zaichick SV. Zinc in human prostate gland: Normal, hyperplastic and cancerous. Journal of Radioanalytical and Nuclear Chemistry. 1997;217(2):157-61.

52. Järup $L$, Åkesson A. Current status of cadmium as an environmental health problem. Toxicology and Applied Pharmacology. 2009;238(3):201-8.

53. Olsson I-M, Bensryd I, Lundh T, Ottosson H, Skerfving S, Oskarsson A. Cadmium in blood and urine--impact of sex, age dietary intake, iron status, and former smoking--association of renal effects. Environmental Health Perspectives. 2002 110(12):1185-90.

54. Julin $B$, Wolk $A$, Johansson $J-E$, Andersson S-O, Andrén $O$, Åkesson A. Dietary cadmium exposure and prostate cancer incidence: a population-based prospective cohort study. British Journal of Cancer. 2012;107(5):895-900.

55. Iseri LT, French JH. Magnesium: Natures physiologic calcium blocker. American Heart Journal. 1984;108(1):188-93.

56. Dai Q, Motley SS, Smith JA, Concepcion R, Barocas D, Byerly S, et al. Blood Magnesium, and the Interaction with Calcium, on the Risk of High-Grade Prostate Cancer. PLoS ONE. 2011(4);6, $1-7$

57. Karimi G, Shahar S, Homayouni N, Rajikan R, Abu Bakar NF, Othman MS, Association between trace element and heavy metal levels in hair and nail with prostate cancer, Asian Pac J Cancer Prev 2012(13): 4249-4253.

58. Nawi AM, Chin SF, Azhar Shah S, Jamal R. Tissue and Serum Trace Elements Concentration among Colorectal Patients: A Systematic Review of Case-Control Studies. Iran J Public Health. 2019:48(4):632-643. 
59. Faris NAAl, Dilshad A. Distribution of Trace Elements like Calcium, Copper, Iron and Zinc in Serum Samples of Colon Cancer - A Case Control Study. Journal of King Saud University - Science, 2011(23); 4: 337-340.

60. Gibb HJ, Lees PS, Pinsky PF, Rooney BC, Lung cancer among workers in chromium chemical production, Am $\mathrm{J}$ Ind Med. 2000;38(2):115-26.

61. Araya M, Pizzaro F, Olivares M, Arredondo M, Gonzales M, Mendez M. Understanding copper homeostasis in humans and copper effects on health. Biol Res 2006(39): 183-187.

62. Mendez WMJr, Eftim S, Cohen J, et al. Relationships between arsenic concentrations in drinking water and lung and bladder cancer incidence in U.S. counties. J Expos Sci Environ Epidemiol. $2017 ;$ 27(3):235-43.

63. Unrine JM, Slone SA, Sanderson W, Johnson N, Durbin EB, Shrestha S. A Case-Control Study of Trace-Element Status and Lung Cancer in Appalachian Kentucky, Plos One, 2019(14); 2:119.

64. Silva MP, Soave DF, Ribeiro-Silva A, Poletti ME. Trace elements as tumor biomarkers and prognostic factors in breast cancer: a study through energy dispersive $x$-ray fluorescence. BMC Research Notes. 2012; (5): 1-11.

65. Peters U, Chatterjee N, Church TR, et al. High serum selenium and reduced risk of advanced colorectal adenoma in a colorectal cancer early detection program. Cancer Epidemiol Biomarkers Prev 2006; 15(2): 315-20.

66. Sherif LR, Howard H. Sky-Peck Comparison between Concentrations of Trace Elements in Normal and Neoplastic Human Breast Tissue. Cancer Research 1984;440:5390-5394.

67. Navarro SA, Silvera $\mathbb{E}$, Thomas E. Rohan. Trace elements and cancer risk: A review of the epidemiologic evidence. Cancer $\mathrm{Ca}-$ uses Control 2007; 18:7-27.

68. Bjelakovic G, Gluud LL, Nikolova D, Bjelakovic M, Nagorni A, Gluud C. Meta-analysis: Antioxidant supplements for liver diseases - the Cochrane Hepato-Biliary Group. Aliment Pharmacol Ther 2010; 32(3): 356-67.

69. Velonas VM, Woo HH, dos Remedios CG, Assinder SJ. Current status of biomarkers for prostate cancer. Int J Mol Sci 2013; 14(6): 11034-60. 
